\title{
Aspects of sustainable development of industry in Kazakhstan
}

\author{
Svetlana Faizullina ${ }^{1 *}$, Ainur Isaeva ${ }^{1}$, Lailya Matkarimova ${ }^{1}$, and Aigul Zhuzbaeva ${ }^{1}$ \\ ${ }^{1}$ Abay Kazakh National Pedagogical University, 050000, Dostyk Avenue, Almaty, Kazakhstan
}

\begin{abstract}
This article discusses the economic benefits of uranium mining, as well as its environmental and health impacts. Sustainable development includes several aspects: energy, water, the environment, food and the economy, and ensuring each of these aspects is a serious problem. Energy is at the center of other aspects of sustainability, as it has a direct relationship with water, food, and the environment. Uranium is Kazakhstan's top priority in the global energy market. In the world, there are different opinions on the development of uranium production, increasing the value of atomic energy. Apparently, this should be preceded by a crisis in the field of oil and gas production in recent years, in connection with which the world energy market should have a diversified course depending on various energy sources. Kazakhstan is a country rich in uranium. In addition, over the years of independence, we have increased production almost four times and maintain leadership in the world. Therefore, uranium production is the most important advantage of our global energy space today.
\end{abstract}

\section{Introduction}

In 2003, nuclear energy again gained interest as a climate-neutral way of satisfying the high-energy needs of large industrialized countries such as China, India, Russia and the United States. This has caused a growing demand for uranium as a nuclear fuel. Called the "nuclear renaissance", the price of uranium rose more than tenfold before the global credit crisis eased the hype.

The main goal of the article is to consider the aspects of sustainable development of the uranium industry in Kazakhstan.

Uranium industry is an important economic activity that can contribute to the development of the economy. At the same time, the impact of the uranium industry on the environment and human health on the environment is of serious concern. The activities of the uranium industry include the use of toxic chemicals and waste disposal, which affects the health of workers and the local population, and has a negative impact on the environment [1]. Health effects can also be caused by pollution of soil and water due to the migration of pollutants as a result of erosion and weathering, as well as the dispersion of

\footnotetext{
Corresponding author: k.bizhanova@inbox.ru
} 
chemicals such as acid effluents from waste [2]. In particular, the extraction and enrichment of uranium caused enormous damage to the environment through the accumulation of waste and improper disposal of radioactive materials, landfill after uranium searches, and other works, especially in the last 60 years after the end of World War II. Large amounts of uranium-containing waste (both high and low) are generated as a result of activities such as fuel fabrication, fuel processing, research and development. All these negative impacts affect the quality of the environment, affect mainly surface and ground waters, soils, at the same time pollute large areas of land, and threaten the catchments of drinking water [3]. Thus, it is clear that pollution caused by uranium has a serious negative biological effect on important groups of the soil food network.

\section{Literature review}

The term "sustainable development" was first used in 1972 at the First World Conference on the Environment in Stockholm. In 1992, at the United Nations Conference on Environment and Development in Rio de Janeiro, the term was used "as the name for a new concept for the existence of all of humanity. The concept of sustainable development was formulated as a way to overcome the main environmental threat for modern civilization, which existed in the form of a certain theoretically substantiated danger, recognized by a relatively narrow circle of scientists and politicians and associated with overpopulation, with the irreplaceable expenditure of natural resources and environmental pollution" [4]. However, E. Loguncev notes, "there is no such concept yet. There are certain ideas that have received general recognition and are fixed in official political decisions. There is not even a generally accepted definition of the term. The actions of the world community are aimed at the formation of the basic elements of the concept, including the development of a conceptual apparatus" [4].

The main conceptual difficulty lies in the fact that the concept of "sustainable development" includes the two terms "sustainability" and "development". Moreover, N. Davydova considers them mutually exclusive and notes "there simply cannot be sustainable development - if there is development, then stability is no longer" [5]. Moreover, Mamedov N.M., on the contrary, notes, "stability does not imply a lack of growth. Sustainable society will be interested in qualitative development and not in physical growth" [7]. According to A.V. Tsvikilevich, the concept of "development" most accurately characterizes the processes that occur when they are used in a much wider sense, as a certain kind of municipal formation strategy, covering the entire system of its main components [8]. According to YArullina G.R., "Development" is a process of expedient continuous irreversible directed regular changes in time, characterized by a transition to a qualitatively new, perfect state [9].

An analysis of recent research and publications has shown that the work of domestic and foreign researchers is devoted to the study of the essence of sustainable development. Therefore, research of Mutanov, G., Ziyadin, S., \& Shaikh, A. A. [10] delves into one of the most pressing problems in improving the assessment of eco-innovative projects meant to effect sustainable development. The problems of sustainable development are now at the center of attention of many foreign and domestic researchers. For example, in the research of Ziyadin, S., Borodin, A., Streltsova, E., Suieubayeva, S., \& Pshembayeva, D. [11] proposes an economic and mathematics models of sustainable tourism development strategic management based on application of fuzzy algebra mathematical apparatus.

David McCandles, considered one of the world masters in creating Infographics, recently created a map showing the best results of each country. It collects the data needed for this map, including various sources of information, ranging from World Bank reports to the Guinness Book of Records. Of course, our Kazakhstan is also included in this map. 
According to David McCandles, Kazakhstan is the best uranium mining country in the world. Kazakhstan takes the first place in explored uranium reserves [13].

According to the Director General of the State Atomic Energy Corporation Sergey Kiriyenko, $98 \%$ of all energy stored on the globe is concentrated on elements such as uranium-238, deuterium, thorium and lithium, which are fodders for atomic energy. Only the remaining 2 percent comes from gas, oil, coal and renewable energy. Moreover, if we talk about real data, then Sergey Kiriyenko noted that $1 \mathrm{~kg}$ of uranium when burning $1 \mathrm{~kg}$ of coal is 88 thousand times more than the energy released when burning $1 \mathrm{~kg}$ of coal. However, does not release any carbon dioxide. Moreover, this situation shows that the potential of nuclear energy on Earth is very large [14]. According to the Minister of Energy of the Republic of Kazakhstan Kanat Bozumbayev, "Uranium mining is one of the most developed areas of the nuclear industry in the country. Uranium is a strategic raw material for nuclear energy and its reserves are limited. Kazakhstan ranks second in the world in proven reserves of natural uranium. About $12 \%$ of all explored world reserves are concentrated in the bowels of the Republic of Kazakhstan. Uranium reserves in the country are estimated at more than 800 thousand tons. At the same time, the total volume of reserves and resources of natural uranium in Kazakhstan is 1.4 million tons. The presence of significant uranium resources is a great competitive advantage of Kazakhstan over other countries". According to him, with rational use for a considerable time - it is closer to 5080 years; Kazakhstan will prevail in comparison with economically developed countries, where natural resources are significantly exhausted [15].

Despite the presence of scientific interest in the study as a whole, currently the unresolved part is the problem of consideration of aspects of sustainable development of the uranium industry of Kazakhstan.

\section{Methodology}

Over the three quarters of 2018, Kazakhstan exported 14.2 thousand tons of uranium, which amounted to 699.1 million dollars in money. Uranium export in money decreased quite significantly - up to $17 \%$ per year, and in tons - by $18.8 \%$ compared to 2017 . In China, which occupies more than half of exports (57\% of total exports), in 2018, 8 thousand tons of uranium were sent, with money 422.6 million US dollars. In second place is Canada (18.2\% of total exports): 2.6 thousand tons, 108.2 million US dollars. The top three importers of Kazakh uranium (16.6\% of total exports) include Russia: 2.4 thousand tons, of which 113.6 million US dollars (Table 1).

Kazakhstan is the leader in uranium mining in the world. So, in 2017, Kazakhstan produced $39.3 \%$ of the world's uranium production, Canada came in second $(22 \%$ of world production), Australia came in third (9.9\%). The three leaders provided $71.2 \%$ of the world's uranium mining (Figure 1).

The national operator for the export and import of uranium and its compounds is the world leader in the production of natural uranium, one of the subsidiaries of JSC NWF Samruk-Kazyna JSC NAC Kazatomprom.

The assets of the national nuclear company include the whole complex of enterprises involved in the production chain of the final product - from exploration, uranium mining, and production of nuclear fuel cycle products to science, social welfare and training. Kazatomprom is the largest uranium producer in the world with natural uranium production in proportion to the share of $23 \%$ of the total global primary uranium production in 2018 . The group has the largest uranium reserve base in the industry. Kazatomprom, together with subsidiaries, affiliates and joint organizations, is developing 26 deposits in the Republic of Kazakhstan, combined into 13 uranium mining enterprises and using underground well leaching technology. As a national nuclear company in the Republic of 
Kazakhstan, the Company has established partnerships with almost all the leading players in the uranium mining industry in the world. The main customers of the Group are nuclear power generation operators, and the main export markets for the Group's products are China, South and East Asia, North America and Europe. The Group sells uranium and uranium products under long-term contracts, short-term contracts, as well as on the spot market directly from its headquarters or through a subsidiary trading company in Switzerland, TNK.

Table 1. Export of natural uranium and its compounds, january-september 2018.

\begin{tabular}{|l|c|c|c|c|c|c|}
\hline & \multicolumn{2}{|c|}{2018} & \multicolumn{2}{c|}{2017} & \multicolumn{2}{c|}{ Annual growth } \\
\hline & tons & $\begin{array}{c}\text { thousand US } \\
\text { dollars }\end{array}$ & tons & $\begin{array}{c}\text { thousand } \\
\text { US dollars }\end{array}$ & tons & $\begin{array}{c}\text { thousand } \\
\text { US dollars }\end{array}$ \\
\hline Total & $\mathbf{1 4}$ & $\mathbf{6 9 9} \mathbf{1 4 3 , 9}$ & $\mathbf{1 7 4 3 2 , 4}$ & $\mathbf{8 4 1 ~ 8 4 8 , 7}$ & $\mathbf{- 1 8 , 8 \%}$ & $\mathbf{- 1 7 , 0 \%}$ \\
\hline EAEU countries & 2353,0 & 113620,0 & 2578,8 & 117990,4 & $-8,8 \%$ & $-3,7 \%$ \\
\hline Russia & 2353,0 & 113620,0 & 2578,8 & 117990,4 & $-8,8 \%$ & $-3,7 \%$ \\
\hline $\begin{array}{l}\text { The rest of the } \\
\text { world }\end{array}$ & 11 & 585523,9 & 14853,6 & 723858,3 & $-20,5 \%$ & $-19,1 \%$ \\
\hline China & 8053,5 & 422608,0 & 11788,9 & 604610,0 & $-31,7 \%$ & $30,1 \%$ \\
\hline Canada & 2574,4 & 108166,7 & 1540,8 & 56369,3 & $67,1 \%$ & $91,9 \%$ \\
\hline France & 788,7 & 36357,3 & 285,8 & 13220,9 & $176,0 \%$ & $175,0 \%$ \\
\hline USA & 385,4 & 18391,9 & 1238,1 & 49656,4 & $-68,9 \%$ & $-63,0 \%$ \\
\hline Austria & 0,00004 & 0,1 & 0,00003 & 1,6 & $25,6 \%$ & $-93,8 \%$ \\
\hline
\end{tabular}

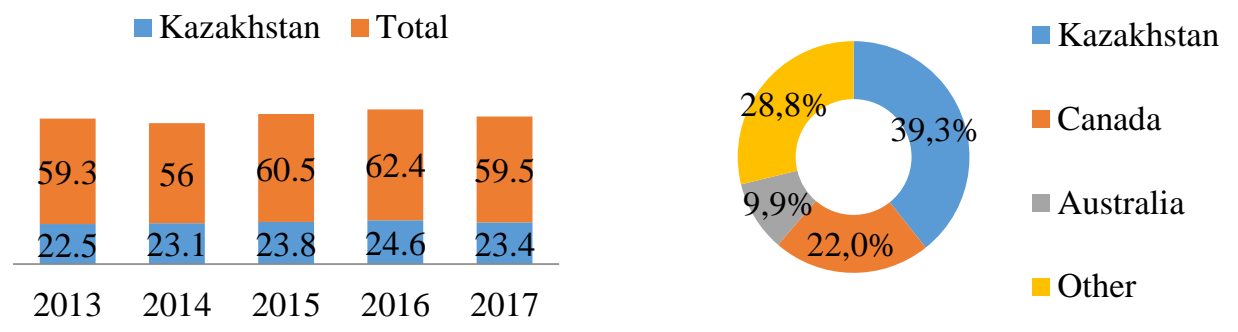

Fig. 1. Uranium mining in Kazakhstan and the share of countries in the world uranium mining (2017).

The national operator for the export and import of uranium and its compounds is the world leader in the production of natural uranium, one of the subsidiaries of JSC NWF Samruk-Kazyna JSC NAC Kazatomprom.

The assets of the national nuclear company include the whole complex of enterprises involved in the production chain of the final product - from exploration, uranium mining, and production of nuclear fuel cycle products to science, social welfare and training. Kazatomprom is the largest uranium producer in the world with natural uranium production in proportion to the share of $23 \%$ of the total global primary uranium production in 2018 . The group has the largest uranium reserve base in the industry. Kazatomprom, together with subsidiaries, affiliates and joint organizations, is developing 26 deposits in the Republic of Kazakhstan, combined into 13 uranium mining enterprises and using underground well leaching technology. As a national nuclear company in the Republic of 
Kazakhstan, the Company has established partnerships with almost all the leading players in the uranium mining industry in the world. The main customers of the Group are nuclear power generation operators, and the main export markets for the Group's products are China, South and East Asia, North America and Europe. The Group sells uranium and uranium products under long-term contracts, short-term contracts, as well as on the spot market directly from its headquarters or through a subsidiary trading company in Switzerland, TNK [18].

According to the latest annual report of NAC Kazatomprom JSC, the three main uranium provinces accounted for $92.7 \%$ of total production in Kazakhstan. In the first place is the Shu-Sarysu province $(60.2 \%)$, in the second - the North Kazakhstan province $(17.3 \%)$, in the third - the Syrdarya province (15.2\%) (Figure2) [19].

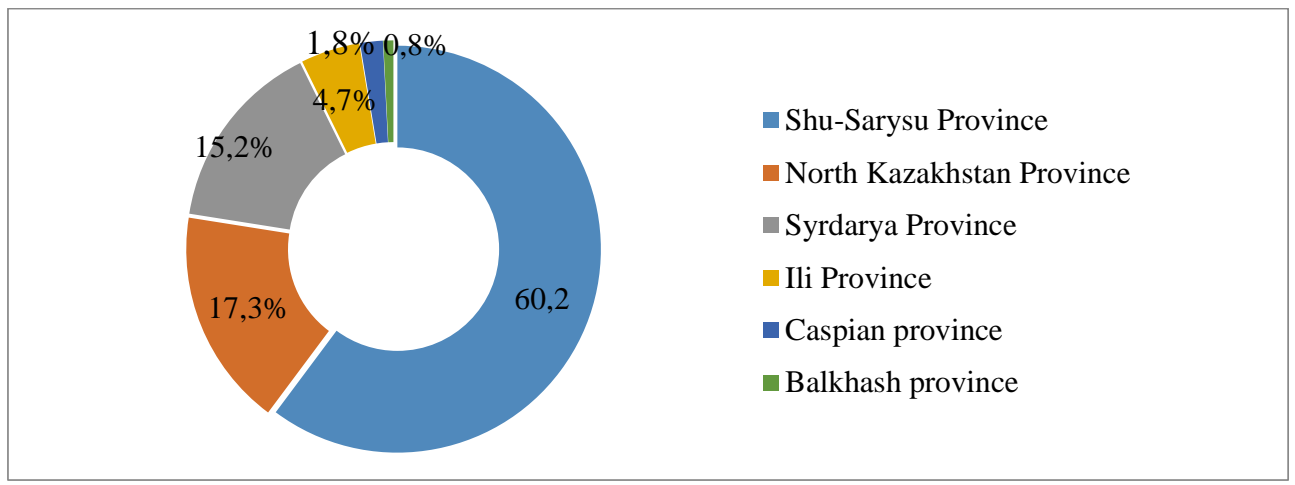

Fig. 2. Uranium provinces of the Republic of Kazakhstan.

Sustainable development includes several aspects: energy, water, the environment, food and the economy, and ensuring each of these aspects is a serious problem. Energy is at the center of other aspects of sustainability, as it has a direct relationship with water, food, and the environment. Uranium mining affects the environment. For sustainable development, much attention needs to be paid to this aspect.

It is known that the extraction of polymetallic ores is not among the environmentally friendly industries. In the Kyzylorda region, uranium ore is poured with concentrated sulfuric acid into the bowels of the earth; rocks are smeared using a pumping unit. After the packing of the ore, obtained in the form of feedstock, in a special container, the not yet enriched uranium ore will not have any radioactive damage to the environment. However, the danger of this production is different. Nevertheless, the danger of this production is also different. It can pollute an underground source of fresh water. In this regard, residents of settlements are forced to resort to pipelines, and settlements where there are no pipelines, to bring water. In order to prevent harmful effects on the environment and human health, a number of measures are being taken at this enterprise.

According to the annual report, Kazatomprom plans to build a refinery (uranium purification plant) based on JSC UMP. The start of construction and installation works is scheduled for early 2019, and the commissioning of the refinery in mid-2020. It is assumed that in the construction of the refinery the technologies and expertise of the Canadian company Cameco will be applied, which at this stage are the most environmentally friendly of all used in the world.

In order to consider aspects of sustainable development of the uranium industry in Kazakhstan, it is necessary to conduct a SWOT analysis that will allow timely prediction of the emergence of threats and potential opportunities. 
Statistical and economic analyzes were used as sources of secondary information. The departmental bodies received the basic data on the studied market of products in the Republic of Kazakhstan, its export and import.

\section{Results and discussion}

In this SWOT analysis (Table 2), we will assess the strengths and weaknesses of the sustainable development aspects of the uranium industry in Kazakhstan, key success factors and opportunities that we have already encountered or may have to face.

Table 2. SWOT- analysis of uranium industry in Kazakhstan

\begin{tabular}{|c|c|}
\hline Strengths & Weaknesses \\
\hline 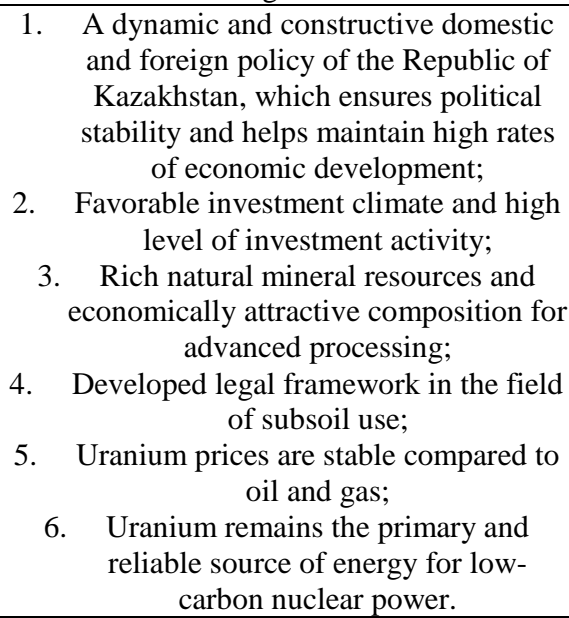 & $\begin{array}{l}\text { 1. Shortage of qualified employees in the } \\
\text { labor market in the mining industry; } \\
\text { 2. High costs of chemical reagents } 27 \% \\
\text { of production costs; } \\
\text { 3. A low level of automation of } \\
\text { production processes leads to a } \\
\text { decrease in the level of management } \\
\text { and control of the production process. } \\
\text { As a result, a decrease in production } \\
\text { efficiency; } \\
\text { 4. Decrease in labor productivity. }\end{array}$ \\
\hline Opportunities & Threats \\
\hline 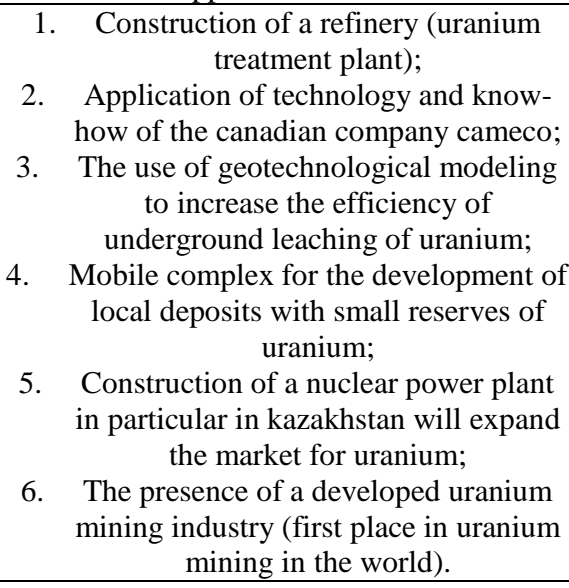 & $\begin{array}{l}\text { 1. Health effects on workers; } \\
\text { 2. Pollution of drinking water; } \\
\text { 3. Negative biological effects on } \\
\text { important groups of the soil food web; } \\
\text { 4. Dispersion of chemicals such as acid } \\
\text { waste effluents; } \\
\text { 5. Depletion of the resource base; } \\
\text { 6. The occurrence of fire hazard } \\
\text { 7ituations; } \\
\text { An increase in the deficit of highly } \\
\text { qualified specialists in the industry. }\end{array}$ \\
\hline
\end{tabular}

To solve the geotechnological and environmental problems that arise during the design and development of deposits using the SST method, specialized mathematical models and software complexes were created at the Seversky Technological Institute, NRNU MEPhI. Currently, the developed software tools are used to improve the efficiency of uranium deposits development by the SST method by Russian enterprises of Dalur JSC and Khiagda JSC. The use of permanent models of the geotechnological field allows you to have up-todate information on the state of GHGs, to constantly monitor production, quickly process 
large amounts of data about the technological process, and use the latest information to optimize the process of natural gas storage.

The permanent model of the geotechnological field combines both technological information obtained in real time and data on the history of field development. Geotechnological calculations are automatically performed by a permanent model based on regularly received technological data from the information system of the mining complex. A permanent model of the geotechnological field provides an answer to the question of what is happening in the GHG at the moment.

The problem of soil pollution can be eliminated by self-cleaning the soil or by performing the following steps:

- cleaning goals;

- form and concentration of pollutants;

- bulk and physico-chemical properties of contaminated soils;

- the effectiveness of rehabilitation;

- targeted use of the cleared area;

- cost associated with the recovery program;

- occupational safety and health risks associated with the technology;

- potential secondary environmental impact (collateral damage);

- previous experience in applying the technology;

- sustainability of any necessary institutional control;

- socio-economic considerations.

\section{Conclusion}

Kazakhstan is the leader in uranium mining in the world. In addition, over the years of independence, we have increased production almost four times and maintain leadership in the world. Therefore, uranium production is the most important advantage of our global energy space today.

Another advantage of uranium is that its price is more stable than the price of oil and gas. Even if oil and gas prices, as well as the current price, fluctuate, their impact on the final product will be so great. Since the cost of uranium is only $4-5 \%$ of the kilowatt-hour power produced at nuclear plants. And now, possessing such great properties, we see that atomic energy so far has a big drawback. This disadvantage arises depending on the safety of its use. The consequences of the accident at nuclear power plants that have occurred in recent years in Ukraine and Japan have destroyed humanity. The central issue for the economy of any country is increasing its economic growth, a reliable driver of which is the formation and development of a strategy for sustainable development of territories based on the intensification of investment activity. Sustainable development is a process of economic and social change, during which a balance is achieved between the exploitation of natural resources, investment activities and scientific and technological development. Therefore, we are not fully exploring the possibilities of atomic energy. It is this shortcoming that does not seem to exaggerate the dynamic development of atomic energy.

\section{References}

1. A. V. Boytsov, V. S Basov, N. V. Putivtseva, Econ. Manag. 6, 80-87. (2008).

2. V. I. Lyashenko, Geol. Explor. 1, 43-52. (2015).

3. V. S. Svyatetskiy, A. A. Morozov, A. A. Gavrilov, Min. J. 8, 43-46. (2008). 
4. Y. Xie, C. Chen, X. Ren, X. Wang, H. Wang, X. Wang, Progr. Mater. Sci. 103, 180234 (2019)

5. M.A. Bahauovna, Int. J. App. Engin. Res , 10(23), 43446-434499 (2015)

6. A. V. Svikilevich, Moscow: Acad. Nat. Sci. 138 (2006)

7. T. V. Runner, Econ. Manag. Fin. 158-163 (2012)

8. G. Mutanov, S. Ziyadin, A. A. Shaikh, Enterpren. Sustain. Issues, 6(4), 2136-2158 (2019)

9. S. Ziyadin, A. Borodin, E. Streltsova, S. Suieubayeva, D. Pshembayeva, Pol. J. Manag. Stud. 19(1), 492-504 (2019)

10. F. Winde, D. Brugge, A. Niedeker, U. Rueg, J. Afr. Earth Sci. 129, 759-778 (2017)

11. E. Ganebnykh, T. Burtseva, A. Petukhova, A. Mottaev, E3S Web Conferences, 91 08035, (2019) doi.org/10.1051/e3sconf / 20199108035

12. Annual reports of NAC Kazatomprom JSC (2018), https://www.kazatomprom.kz/ru/investors/godovie_otcheti.

13. V. G. Ivanov, V. I. Kultyshev, V. B. Kolesaev, V. G. Litvinenko, V. G. Sheludchenko, Optimization of development of complex structural uranium deposits. Tutorial (2007)

14. D. E. Crean, F. R. Livens, M. Sajih, M. C. Stennett, D. Grolimund, C. N. Borca, N.C Hyatt,. J. Hazard.Mater. 263, 382-390 (2013)

15. M. D. Noskov, A. D. Istomin, A. G. Kesler, S. N. Noskova, Eco. Syst. Dev.10, 33-37 (2008)

16. A. Chamaret, M. O'Connor, G. Recoce, Top-down and bottom-up approach for developing sustainable development indicators in the mining industry: use in Arlit (Niger) uranium mines (2007)

17. S. Ziyadin, E. Streltsova, et al. Sustain. 11, 9, 2544 (2019) 